\title{
Gall Wasps, Callirhytis quercusclaviger (Ashmead) and Callirhytis cornigera (Osten Sacken) (Insecta: Hymenoptera: Cynipidae) ${ }^{1}$
}

Wayne N. Dixon ${ }^{2}$

\section{Introduction}

Callirhytis quercusclaviger (Ashmead) causes the "spine-bearing potato gall" on laurel oak, Quercus laurifolia Michx., in Florida (Ashmead 1881). The horned oak gall, caused by Callirhytis cornigera (Osten Sacken), occurs on water oak, Quercus nigra L., as well as several other Quercus spp. (Drooz 1985, Osten Sacken 1862).

Generally, individual trees or small groups of trees become slightly to moderately infested by these Callirhytis spp. Widespread infestations are not common (Kinsey 1935). However, severe gall wasp infestations have been observed in several Florida counties. Extremely high numbers of twig galls of $C$. quercusclaviger have occurred on thousands of laurel oaks in several locations. These infestations have affected young to mature trees in woodlands and residential areas. The overabundance of twig galls has resulted in notable levels of branch dieback, crown thinning, and tree mortality.

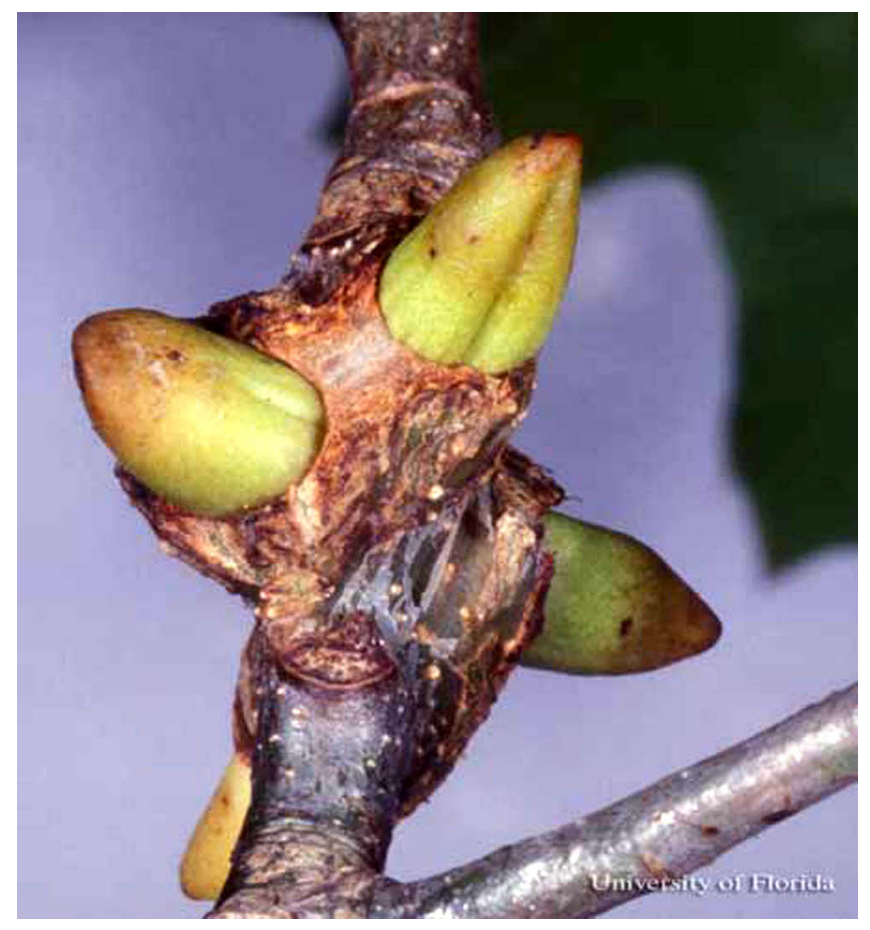

Figure 1. Mature (with horns) spine-bearing potato gall caused by the gall wasp Callirhytis quercusclaviger (Ashmead). Credits: Lyle J. Buss, University of Florida

1. This document is EENY-368 (IN665), one of a series of Featured Creatures (originally published as DPI Entomology Circular 355) from the Entomology and Nematology Department, Florida Cooperative Extension Service, Institute of Food and Agricultural Sciences, University of Florida. Published: May, 2006. This document is also available on Featured Creatures Website at http://creatures.ifas.ufl.edu. Please visit the EDIS Website at http://edis.ifas.ufl.edu.

2. Wayne N. Dixon, Florida Department of Agriculture and Consumer Services, Division of Plant Industry, Gainesville, FL.

The Institute of Food and Agricultural Sciences (IFAS) is an Equal Opportunity Institution authorized to provide research, educational information and other services only to individuals and institutions that function with non-discrimination with respect to race, creed, color, religion, age, disability, sex, sexual orientation, marital status, national origin, political opinions or affiliations. U.S. Department of Agriculture, Cooperative Extension Service, University of Florida, IFAS, Florida A. \& M. University Cooperative Extension Program, and Boards of County Commissioners Cooperating. Larry Arrington, Dean 


\section{Distribution}

Specific records and observations are from Alachua, Duval, Lake, Leon, Marion, Orange, Polk, Sumter, Suwannee and Wakulla counties. However, it is likely both Callirhytis spp. occur throughout the ranges of their respective host oaks in Florida. Both species also occur from Georgia north to southern Canada (Johnson and Lyon 1994).

\section{Identification}

Galls: Mature twig galls remain as individual swellings or form massive compound galls more than $5 \mathrm{~cm}$ in diameter and up to $20 \mathrm{~cm}$ long (Osten Sacken 1862, Taft and Bissing 1988).

Young galls are slight, tumor-like swellings of periderm tissue. Bark color of young galls is a greenish-brown and bark surfaces are smooth except for protruding lenticels (Taft and Bissing 1988).

If sufficiently mature, twig galls exhibit spines or horns. Older galls become very woody, discolored, and horns will be absent (Ashmead 1881). Galls are pathologically developed tissues. Cell hypertrophy (over-growth) and hyperplasia (cell proliferation) result in gall formation (Mani 1964).

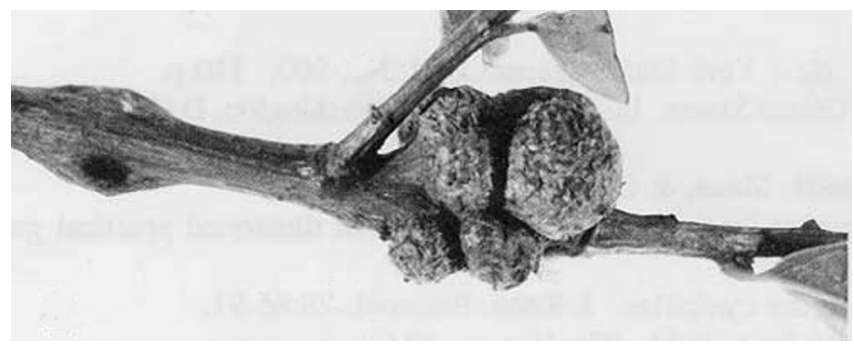

Figure 2. Young spine-bearing potato gall caused by the gall wasp Callirhytis quercusclaviger (Ashmead). Credits: Jeffery Lotz, DPI

Adult wasp: In C. quercusclaviger, the female body is generally reddish-brown with the abdomen much deeper than long and brownish-black on the dorsum. The female's ovipositor projects at a 45-degree angle. The wings are yellowish and about 2 $\mathrm{mm}$ long (Ashmead 1881). C. cornigera is similar in appearance.

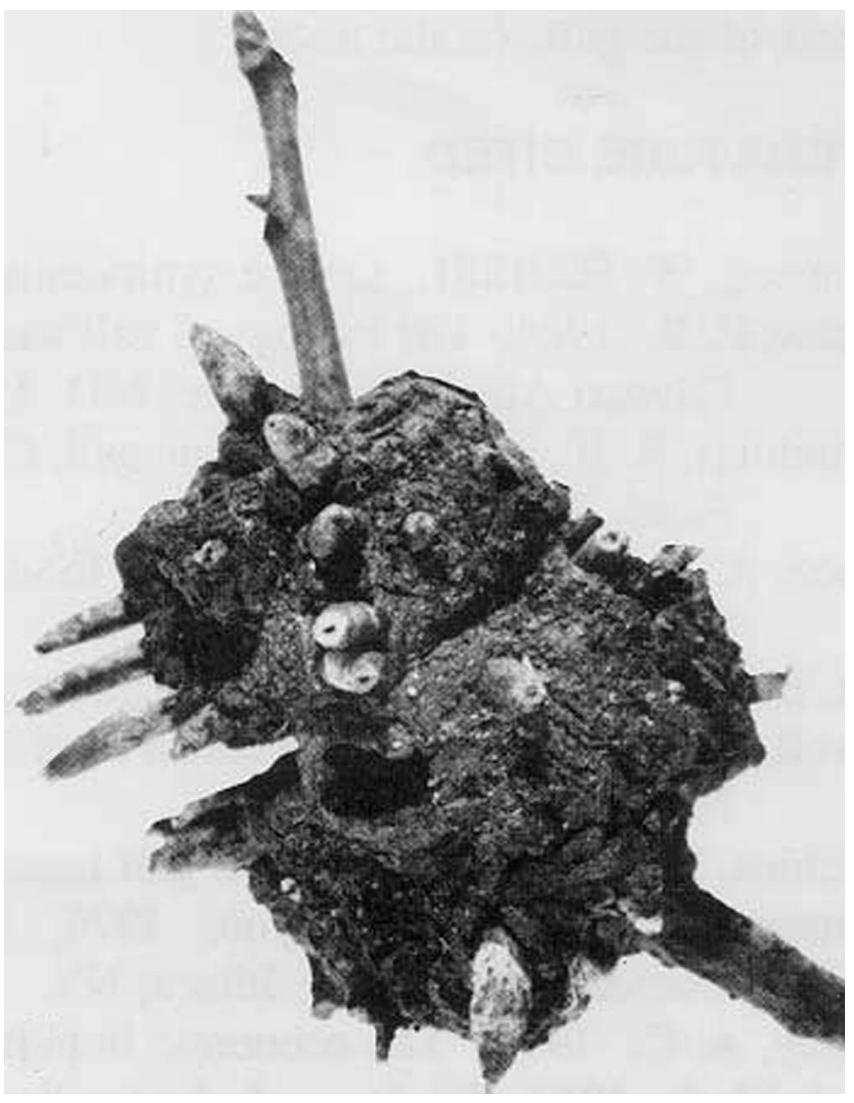

Figure 3. Mature (with horns) spine-bearing potato gall caused by the gall wasp Callirhytis quercusclaviger (Ashmead). Credits: Jeffery Lotz, DPI

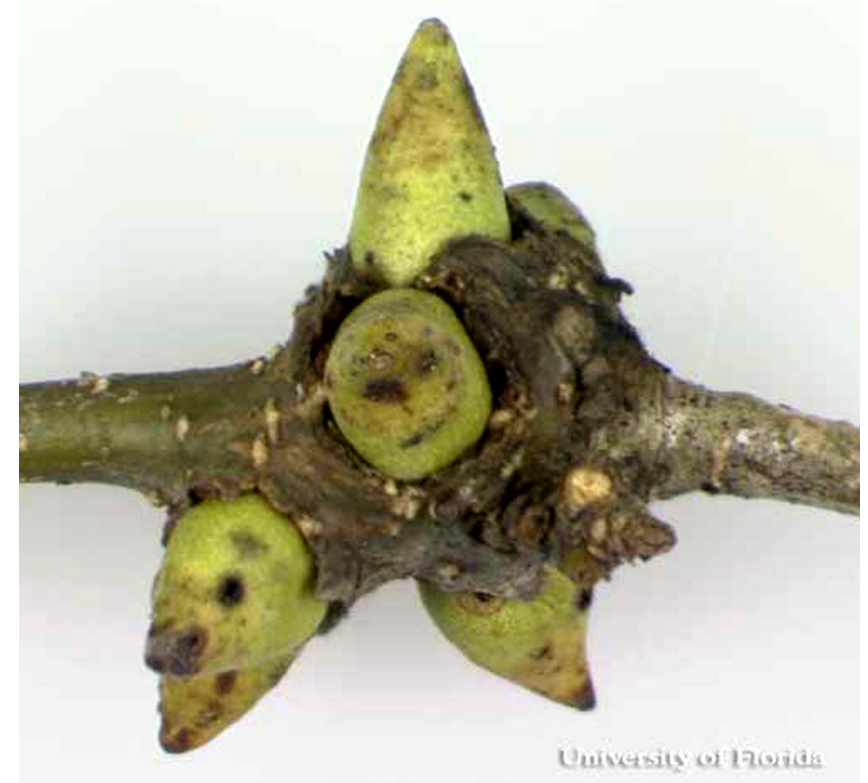

Figure 4. Mature (with horns) spine-bearing potato gall caused by the gall wasp Callirhytis quercusclaviger (Ashmead). Credits: Lyle J. Buss, University of Florida 


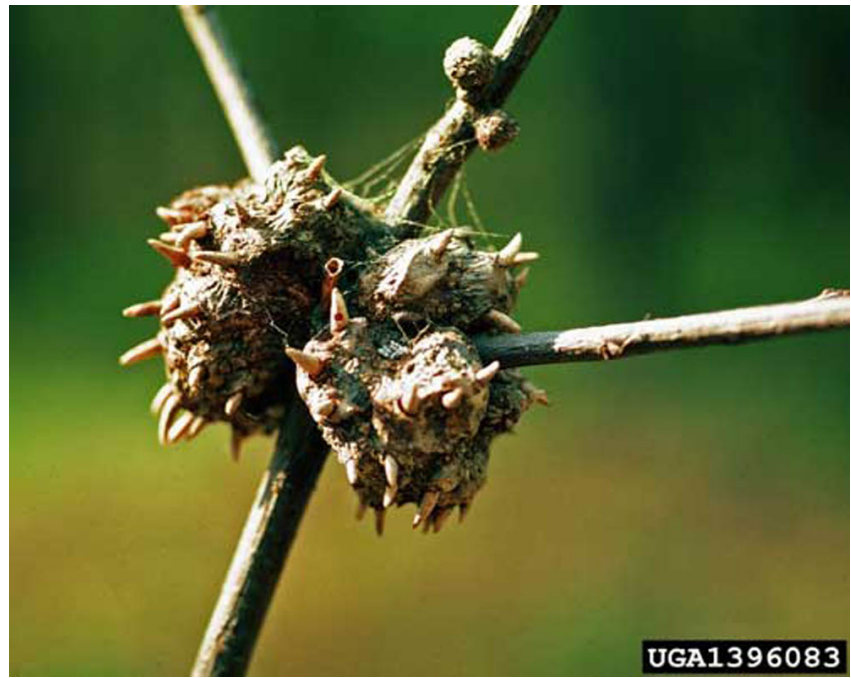

Figure 5. Mature horned oak galls caused by the gall wasp Callirhytis cornigera (Osten Sacken). Credits: USDA Forest Service, www.forestryimages.org

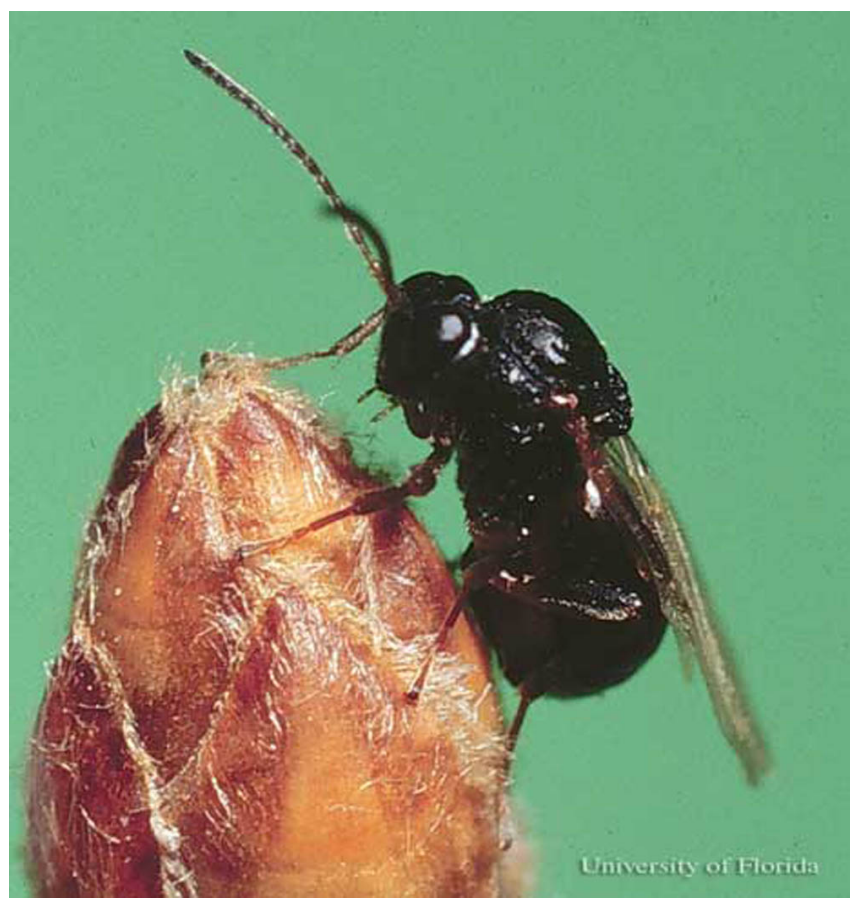

Figure 6. Adult gall wasp, Callirhytis cornigera (Osten Sacken). Credits: Eileen Buss, University of Florida

\section{Biology}

Little information is available for $C$. quercusclaviger. The apparent life cycle of $C$. cornigera is complicated. In New York, parthenogenic female wasps emerge from twig galls in May and June. These females oviposit eggs on veins on the underside of leaves. Small vein galls appear from late May through June. Male and female wasps emerge from the vein galls in early July. Mated females oviposit eggs in young oak twigs. Twig galls appear the following spring. Two or more years are required for the immature gall wasps to complete development in the twig galls.

The galls provide shelter, protection, and food for the immature wasps (Hutchins 1969). Inside a gall, the larvae are surrounded by tissues (nutritive zone) rich in nutrients (Askew 1984). As the larvae reach maturity small spines or horns become evident on the gall. An adult wasp emerges from each horn (Johnson and Lyon 1976).

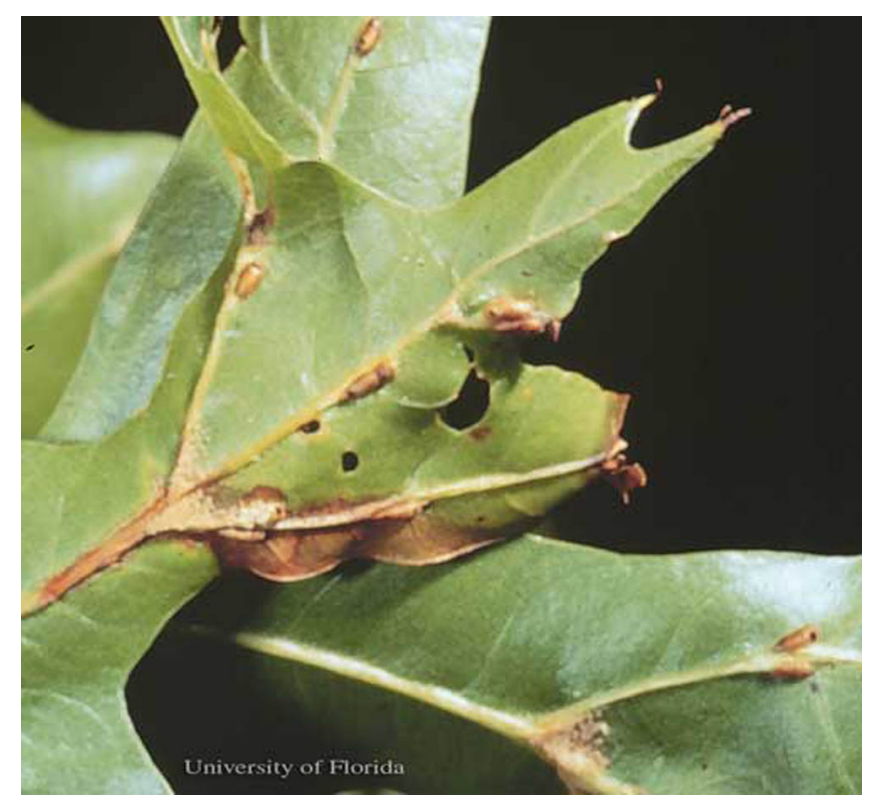

Figure 7. Leaf vein galls of the gall wasp, Callirhytis cornigera (Osten Sacken). Credits: Eileen Buss, University of Florida

\section{Economic Importance}

Twig galls can cause severe injury, loss of growth, and tree mortality (Johnson and Lyon 1976, Drooz 1985, Cummings 1976). The horned oak gall apparently becomes epidemic periodically in some areas and has killed thousands of pin oak, Quercus palustris Muench (Taft and Bissing 1988). Twig galls result in disruption of the vascular tissues through the galled area. Normal transportation of photosynthates, water, and minerals becomes severely limited to and from leaves (Taft and Bissing 1988). In Florida, mature laurel oak trees in residential areas have succumbed to severe gall wasp infestations. Severe branch dieback and crown thinning are commonly observed on many laurel oaks. 


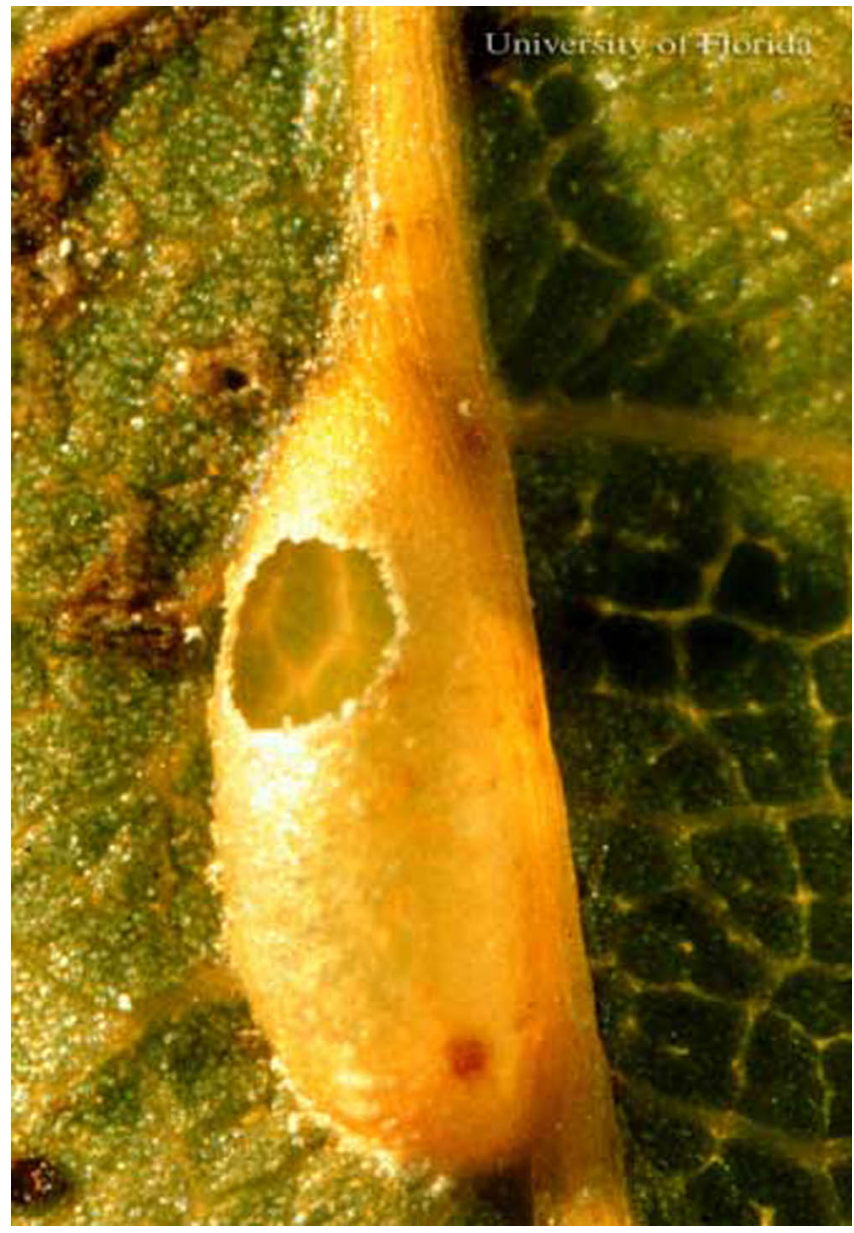

Figure 8. Adult emergence hole in a leaf vein gall of the gall wasp, Callirhytis cornigera (Osten Sacken). Credits: Eileen Buss, University of Florida

Johnson and Lyon (1994) report that $C$. cornigera attacks the twigs of pin, scrub, black blackjack and laurel oak from Georgia to southern Canada, while C. quercusclaviger infests twigs of scarlet, red, pin, and black oak.

\section{Survey}

Symptoms of infestation include branches exhibiting knotty, oval or spherical enlargements (galls) varying in size with horn-like projections. Galls may be present on all branches.

\section{Management}

Management of these gall wasps is difficult. Prune infested branches where possible. Systemic insecticides may prove somewhat useful. In several large infestations investigated in Florida, the common variables were extremely high densities of laurel oak growing on sandy soils that are deeply

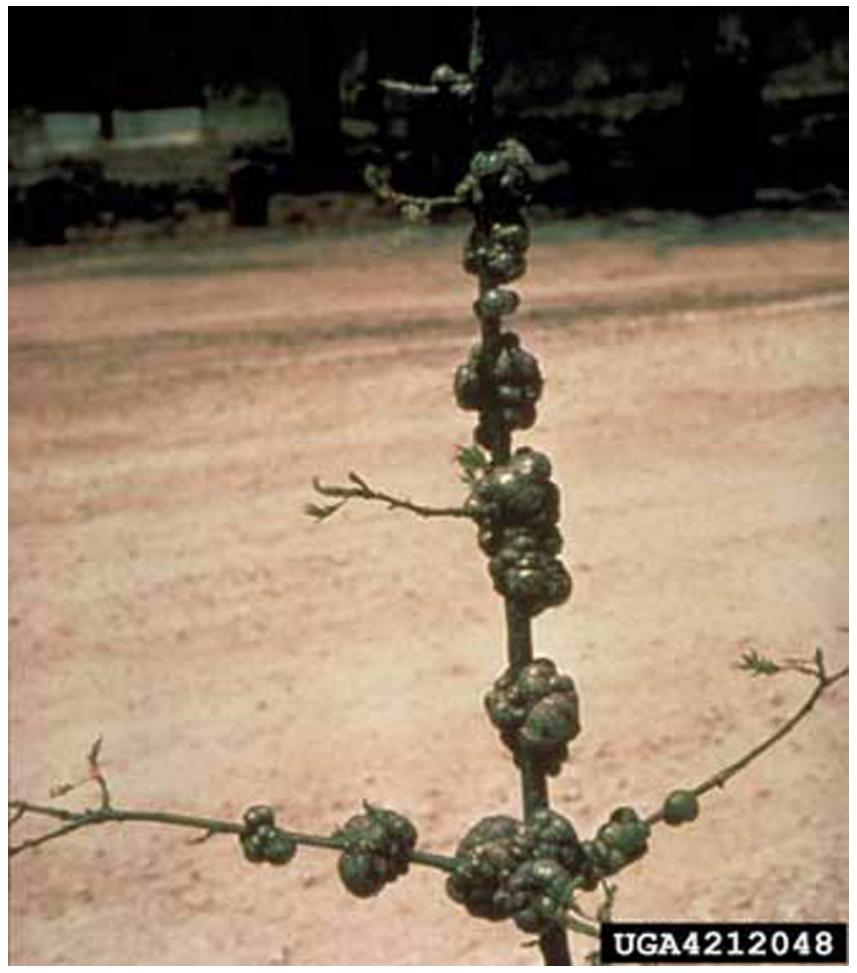

Figure 9. Mature horned oak galls caused by the gall wasp Callirhytis cornigera (Osten Sacken). Credits: Minnesota Department of Natural Resources, www.forestryimages.org

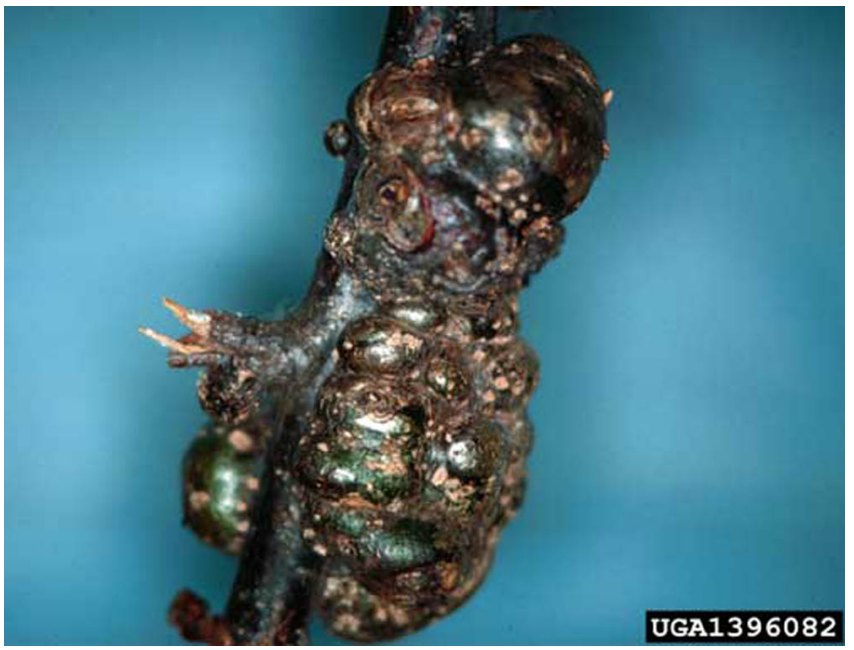

Figure 10. Young horned oak galls caused by the gall wasp Callirhytis cornigera (Osten Sacken). Credits: USDA Forest Service, www.forestryimages.org

drained, strongly acidic, and with low fertility (e.g., Alpin and Blanton soils). The high oak density apparently resulted from exclusion of fire - laurel oak is very susceptible to fire (Fowells 1965). Today, laurel oaks are often considered weeds due to their success in establishment and resulting densities. The stress of an ongoing, multi-year drought cycle may exacerbate the effects of the galls on the trees. 


\section{Selected References}

Ashmead WH. 1881. On the cynipidous galls of Florida. American Entomological Society

Transactions 9: xxiv-xxviii.

Askew RR. 1984. The biology of gall wasps, Chapter 8. In Ananthakrishnan TN. (ed.). Biology of gall insects. Edward Arnold, Baltimore, MD 8:

223-271.

Cummings RB. 1976. Horned oak gall, Callirhytis punctata (O.S.) on pin oak in LaPorte Co., Ind. Proceedings of the Indiana Academy of Science 1976: 230.

Drooz AT. 1985. Insects of Eastern Forests. USDA Forest Serv., Washington, D.C. Miscellaneous Publication No. 1426. 608 p.

Felt E. 1917. Key to American insect galls. New York State Museum Bulletin No. 200. 310 p.

Fowell HA. 1965. Silvics of forest trees of the United States. USDA Forest Service, Washington, D.C. Agricultural Handbook No. 271: 581-583.

Hutchins RE. 1969. Galls and Gall Insects. Dodd, Mead, \& Co., NY. 128 p.

Johnson WT, Lyon HH. 1976. Insects That Feed on Trees and Shrubs. An illustrated practical guide. Cornell University. Press, Ithaca, NY. 463 p.

Johnson WT, Lyon HH. 1994. Insects That Feed on Trees and Shrubs. An illustrated practical guide. 2nd ed. rev. Cornell University. Press, Ithaca, NY. $560 \mathrm{p}$.

Kinsey AC. 1935. The economic importance of the cynipidae. Journal of Economic Entomology 28: 86-91.

Mani MS. 1964. Ecology of Plant Galls. Dr. W. Junk, Publ. The Hague. 434 p.

Mizell RF, Fasulo TR, Short DE. 2005. Galls. Woodybug. http://woodypest.ifas.ufl.edu/galls.htm (27 April 2006).

Osten Sacken R. 1862. Additions and corrections to the paper entitled: "On the Cynipidae of the North
American oaks and their galls." Proceedings of the Entomological Society of Philadelphia. 1: 241-259.

Taft JB, Bissing DR. 1988. Developmental anatomy of the horned oak gall induced by Callirhytis cornigera on Quercus palustris (pin oak). American Journal of Botany 75: 26-36. 